\title{
Degradation and Leaching Behavior of the Pyrethroid Insecticide Cypermethrin in Soils
}

\author{
Shinoi Sakata, Nobuyoshi Mikami, Tadashi Matsuda \\ and Junshi Mryamoto \\ Laboratory of Biochemistry and Toxicology, Takarazuka Research Center, \\ Sumitomo Chemical Co., Ltd., Takatsukasa, Takarazuka 665, Japan
}

(Received August 8, 1985)

\begin{abstract}
The degradation of $(1 R, c i s)$ - and $(1 R$, trans $)$-isomers of cypermethrin $[(R S)$ - $\alpha$-cyano-3phenoxybenzyl (1RS)-cis,trans-3-(2,2-dichlorovinyl)-2,2-dimethylcyclopropanecarboxylate] in two soils was studied under laboratory conditions, using ${ }^{14} \mathrm{C}$ preparations labeled separately in the cyclopropyl and benzyl rings. The half-life of disappearance was 4.1 to 17.6 days for the trans-isomer and 12.5 to 56.4 days for the cis-isomer. The insecticide was degraded via pathways including cleavage of the ester or diphenyl ether bond, hydroxylation at the 4-position of the phenoxy ring, and hydrolysis of the cyano group to the amide and carboxyl groups. The main degradation route was hydrolysis of the ester linkage. The resultant products underwent further degradation to form ${ }^{14} \mathrm{CO}_{2}$ and bound residues. A larger amount of ${ }^{14} \mathrm{CO}_{2}$ was evolved in soils treated with the less persistent trans-isomer and with the benzyl-14C preparation. In contrast, a larger amount of bound ${ }^{14} \mathrm{C}$ was formed in soils treated with the cis-isomer and with the cyclopropyl- ${ }^{14} \mathrm{C}$ preparation. Although a trace amount of cypermethrin appeared in the effluent from sand containing less than $0.1 \%$ organic matter, there was no leaching of cypermethrin with water through other three types of soil columns, when leaching was started immediately after treatment or after a 30-day preincubation of the treated soil columns.
\end{abstract}

\section{INTRODUCTION}

Cypermethrin $[(R S)-\alpha$-cyano-3-phenoxybenzyl (1RS)-cis,trans-3-(2,2-dichlorovinyl)-2,2-dimethylcyclopropanecarboxylate] is one of the most potent synthetic pyrethroid insecticides currently used for agriculture. The insecticide has three chiral centers in the molecule, being a mixture of eight isomers. From the viewpoint of environmental safety, metabolism of cypermethrin in soils, ${ }^{1,2)}$ plants $^{3)}$ and rats ${ }^{4,5)}$ as well as its photodegradation ${ }^{6,7)}$ has been studied. The previous studies have shown that the $(1 R S, c i s)$ - and (1RS,trans)-isomers decompose in soils collected in Spain and UK, via oxidation and hydrolysis followed by degradation of the resultant products to $\mathrm{CO}_{2}$ and bound residues. ${ }^{1,2)}$

The experiments have now been extended, and two types of Japanese soils treated with the radiolabeled (1R,trans)- and ( $1 R$, cis $)$ isomers were analyzed, after a 24-week storage in the laboratory, to obtain more detailed information on the degradation profile. The leaching behavior of cypermethrin in four types of soils were also examined.

\section{MATERIALS AND METHODS}

\section{Chemicals}

Samples of cis- and trans-cypermethrin labeled with ${ }^{14} \mathrm{C}$ separately at the $\mathrm{C}-1$ position of the cyclopropyl ring, referred to as [cyclopropyl $\left.-{ }^{14} \mathrm{C}\right]$, and also at the benzyl ring, referred to as [benzyl $\left.-{ }^{14} \mathrm{C}\right]$, were synthesized by Kana-

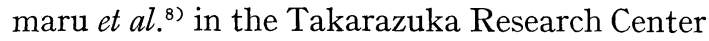
of Sumitomo Chemical Co., Ltd. The specific activity was $22.0 \mathrm{mCi} / \mathrm{mmol}$ for the cyclopropyl ${ }^{14} \mathrm{C}$ and $25.2 \mathrm{mCi} / \mathrm{mmol}$ for the benzyl${ }^{14} \mathrm{C}$. The radiochemical purity of all samples was more than $98.2 \%$, as determined by silica 
Table 1 Thin-layer chromatographic properties of cypermethrin isomers and their degradation products.

\begin{tabular}{|c|c|c|c|c|c|}
\hline \multirow{2}{*}{ Compound } & \multicolumn{5}{|c|}{$R f$ values with indicated solvent systems ${ }^{a}$ ) } \\
\hline & $\mathrm{A}$ & B & $\mathrm{C}$ & $\mathrm{D}$ & $\mathrm{E}$ \\
\hline$c i s-\mathbf{I}$ & $\begin{array}{l}0.60 \\
0.56\end{array}$ & 0.64 & 0.56 & 0.67 & 0.71 \\
\hline trans-I & $\begin{array}{l}0.52 \\
0.48\end{array}$ & 0.63 & 0.54 & 0.67 & 0.69 \\
\hline II & - & 0.30 & 0.28 & - & 0.48 \\
\hline III & - & 0.30 & 0.23 & 0.51 & 0.48 \\
\hline IV & - & 0.33 & 0.17 & 0.45 & $\begin{array}{l}0.35 \\
0.30\end{array}$ \\
\hline $\mathbf{V}$ & - & 0.05 & 0.04 & - & 0.20 \\
\hline$c i s-\mathbf{V I}$ & - & 0.49 & 0.44 & 0.45 & 0.58 \\
\hline trans-VI & - & 0.46 & 0.33 & 0.38 & 0.53 \\
\hline VII & - & 0.39 & 0.20 & 0.32 & 0.51 \\
\hline VIII & - & 0.35 & 0.80 & 0.66 & $\begin{array}{l}0.55 \\
0.52\end{array}$ \\
\hline IX & - & $\begin{array}{l}0.59 \\
0.45\end{array}$ & - & $\begin{array}{l}0.53 \\
0.40\end{array}$ & - \\
\hline
\end{tabular}

a) A: hexane/diethyl ether (20/1, 6 times), B: hexane/toluene/acetic acid (3/15/2), C: hexane/acetone (4/1, 2 times), D: toluene/diethyl ether/acetic acid $(75 / 25 / 1)$, E: benzene saturated with formic acid/diethyl ether (10/3).

gel thin-layer chromatography (TLC) in solvent system A shown in Table 1.

The unlabeled cis- and trans-cypermethrin (designated as cis- and trans-I), along with the following compounds were synthesized in our laboratory for reference purposes ${ }^{1-5)}:(R S)$ $\alpha$-cyano-3-hydroxybenzyl (1R)-cis, trans-3-(2,2dichlorovinyl) - 2, 2 - dimethylcyclopropanecarboxylate (II), (RS)- $\alpha$-cyano-3-(4-hydroxyphenoxy)benzyl (1R)-cis,trans-3-(2,2-dichlorovinyl)2,2-dimethylcyclopropanecarboxylate (III), $(R S)$ - $\alpha$-carbamoyl-3-phenoxybenzyl $(1 R)$-cis, trans-3-(2, 2-dichlorovinyl)-2, 2-dimethylcyclopropanecarboxylate (IV), (RS)- $\alpha$-carbamoyl-3hydroxybenzyl (1R)-cis,trans-3-(2, 2-dichlorovinyl) - 2, 2 - dimethylcyclopropanecarboxylate (V), (1R,3S)-cis,trans-3-(2,2-dichlorovinyl)-2,2dimethylcyclopropanecarboxylic acid (VI), 3phenoxybenzoic acid (VII), (1R,3S)-cis,trans-3(2, 2-dichlorovinyl) -2-methylcyclopropane-1, 2dicarboxylic acid (VIII), (RS)- $\alpha$-carboxy-3phenoxybenzyl (1R)-cis, trans-3-(2, 2-dichlorovinyl) - 2, 2 - dimethylcyclopropanecarboxylate (IX).

\section{Radioassay}

Liquid scintillation counting (LSC), combustion analysis and autoradiography were carried out according to the methods reported previously. ${ }^{9)}$

\section{Thin-layer Chromatography (TLC)}

The precoated silica gel $60 \mathrm{~F}-254$ chromatoplates $(20 \times 20 \mathrm{~cm}, \quad 0.25 \mathrm{~mm}$ thickness, E. Merck) were used for analytical and preparative purposes. The $R f$ values of cis- and trans-I and their derivatives by TLC using five solvent systems are shown in Table 1. The solvent systems for two-dimensional development are illustrated, for example, as follows: $(B, C)$ indicates the development in the first direction with solvent system B and in the second direction with solvent system $\mathrm{C}$. The radioactive spots on the TLC plates were detected by autoradiography, and the unlabeled compounds by ultraviolet light.

\section{Soils}

Two kinds of soils were collected from upland fields in Japan (Kuki in Saitama Pref. and Azuchi in Shiga Pref.) for the metabolism study, and four kinds of upland soils (Sapporo in Hokkaido, Kodaira in Tokyo Metropolis, Muko and Takarazuka in Hyogo Pref.) for the leaching study. Their properties were characterized according to the methods de- 
Table 2 Characteristic of soils used in the experiment.

(Dry soil basis)

\begin{tabular}{|c|c|c|c|c|c|c|}
\hline & Kuki & Azuchi & Sapporo & Kodaira & Muko & Takarazuka \\
\hline Soil texture & Clay loam & $\begin{array}{l}\text { Sandy clay } \\
\text { loam }\end{array}$ & Clay loam & Clay loam & Sand & Sandy loam \\
\hline \multicolumn{7}{|l|}{ Soil particles (\%) } \\
\hline Sand & 70.2 & 62.5 & 56.0 & 31.0 & 99.0 & 78.0 \\
\hline Silt & 22.6 & 17.0 & 22.0 & 40.0 & 1.0 & 7.0 \\
\hline Clay & 7.2 & 20.5 & 22.0 & 29.0 & 1.0 & 14.0 \\
\hline Clay mineral & - & Kaolinite & Allophane & Allophane & - & - \\
\hline $\begin{array}{l}\text { Organic matter } \\
\text { content }(\%)\end{array}$ & 6.2 & 0.4 & 11.0 & 15.3 & 0.1 & 2.3 \\
\hline $\begin{array}{l}\text { Cation exchange } \\
\text { capacity (me) }\end{array}$ & 34.0 & 13.2 & 41.9 & 53.7 & 2.3 & 9.7 \\
\hline $\mathrm{pH}$ & 5.7 & 5.5 & 5.3 & 5.5 & 7.8 & 6.2 \\
\hline Water content (\%) & 38.3 & 13.0 & 29.0 & 49.3 & $<0.1$ & 8.9 \\
\hline $\begin{array}{l}\text { Maximum water- } \\
\text { holding capacity (\%) }\end{array}$ & 135.8 & 63.1 & 93.0 & 148.5 & 33.5 & 55.9 \\
\hline
\end{tabular}

scribed in a text book, ${ }^{10)}$ and the results are summarized in Table 2. The soil samples were kept at $0-4^{\circ} \mathrm{C}$ in the dark and passed through a 2-mm sieve prior to use.

\section{Degradation Study in Soils}

The soil equivalent to $30 \mathrm{~g}$ on an oven-dry weight basis was taken into a $50-\mathrm{ml}$ beaker and the moisture was adjusted to $40 \%$ of the maximum water-holding capacity. To the samples, after a 2 -week preincubation at $25 \pm$ $2{ }^{\circ} \mathrm{C}$ in the dark, the radiolabeled isomers of $\mathbf{I}$ (30 $\mu \mathrm{g}$ in $100 \mu \mathrm{l}$ of acetone) were applied. The treated soils were mixed thoroughly to give a concentration of $1.0 \mathrm{ppm}$, placed in a $3-l$ glass jar covered with aluminum foil and kept at $25 \pm 2{ }^{\circ} \mathrm{C}$ for 24 weeks. Each jar was continuously purged with the $\mathrm{CO}_{2}$-free air at a flow rate of $25-30 \mathrm{ml} / \mathrm{min}$, and the effluent air was passed in sequence through a polyurethane foam plug ${ }^{11)}$ and a gas washing bottle containing $400 \mathrm{ml}$ of $0.5 \mathrm{~N} \mathrm{NaOH}$ solution, trapping the volatile ${ }^{14} \mathrm{C}$ including ${ }^{14} \mathrm{CO}_{2}$. The moisture content of the soils was readjusted periodically to the original value by adding distilled water. The polyurethane foam plugs and the alkaline solution were replaced every two weeks. The polyurethane foam was eluted with methanol $(30 \mathrm{ml} \times 3)$ for ${ }^{14} \mathrm{C}$ analysis and the $\mathrm{NaOH}$ solution was radioassayed using Aquasol ${ }^{\circledR}$-2. To determine ${ }^{14} \mathrm{CO}_{2}, 1 \mathrm{ml}$ of $1 \mathrm{~N} \mathrm{BaCl} l_{2}$ solution was added to $10 \mathrm{ml}$ of the $\mathrm{NaOH}$ solution and the supernatant fraction, separated by centrifugation of the precipitate $\left(\mathrm{Ba}^{14} \mathrm{CO}_{3}\right)$, was radioassayed.

At various time intervals, the incubated soils were extracted with methanol $(60 \mathrm{ml} \times 3)$ by shaking for $10 \mathrm{~min}$. The methanol extracts, separated by centrifugation at $5000 \mathrm{rpm}$ for $10 \mathrm{~min}$, were combined, radioassayed and concentrated to dryness in a rotary vacuum evaporator. The residues were redissolved in methanol, an aliquot of which was subjected to TLC for analysis of the degradation products. Through extraction, autoradiography and LSC as described above, $96.7-101.0 \%$ of the applied $\mathbf{I}$ isomers were recovered from Kuki and Azuchi soils immediately after the application of cyclopropyl- ${ }^{14} \mathrm{C}$ I at a rate of $1 \mathrm{ppm}$.

The unextracted soil residues were dried, sampled in duplicate $(300 \mathrm{mg})$ and combusted to ${ }^{14} \mathrm{CO}_{2}$ prior to LSC. Aliquots of the bound ${ }^{14} \mathrm{C}$ were fractionated into fulvic acid, humic acid and humin fractions according to the method described in a previous publication. ${ }^{12)}$ The fulvic acid fraction was extracted with ethyl acetate $(200 \mathrm{ml} \times 3)$, the organic and aqueous fraction being radiocounted. The organic layer was concentrated and examined by TLC.

\section{Leaching Study}

Either Sapporo soil (118.2 g on an air-dry weight basis), Kodaira soil (120.6 g), Muko sand (191.9 g) or Takarazuka soil (163.4 g) was 
packed uniformly up to $25 \mathrm{~cm}$ from the bottom in a glass column $2.5 \mathrm{~cm}$ i.d. and $40 \mathrm{~cm}$ long. The column was conditioned prior to use by running water at a rate of $6-10 \mathrm{ml} /$ day until the effluent was clear. Onto the column, the soil (23-39 $\mathrm{g}$ on an air-dry weight basis) treated with $1 \mathrm{ppm}$ of either cyclopropyl- or benzyl- ${ }^{14} \mathrm{C}$ I (cis/trans $=1 / 1$ mixture) was placed immediately after mixing or after a 30-day incubation in a stoppered glass flask under aerobic upland conditions at $25 \pm 2{ }^{\circ} \mathrm{C}$ in the dark. The glass flask was purged with the $\mathrm{CO}_{2-}$ free air, and ${ }^{14} \mathrm{CO}_{2}$ evolved during the incubation was trapped in a $0.5 \mathrm{~N} \mathrm{NaOH}$ solution as described above.

To the top of the treated soil column, 1000 $\mathrm{ml}$ of distilled water was applied at a rate of $3 \mathrm{ml} / \mathrm{hr}$ for 3 weeks by an automatic dispenser in such a way that no water-layer would build up on the soil. During the percolation the column was covered with aluminum foil, kept at $25 \pm 2{ }^{\circ} \mathrm{C}$ and the effluxed air was passed through a $0.5 \mathrm{~N} \mathrm{NaOH}$ solution to trap ${ }^{14} \mathrm{CO}_{2}$ evolved in the soil column.

After the column had been allowed to drain off, the soil was taken out of the column and divided transversely into 6 fractions (treated soil, 0-5 cm, 5-10 cm, $10-15 \mathrm{~cm}, 15-20 \mathrm{~cm}, 20$ $25 \mathrm{~cm}$ downward from the top).

Samples $(1 \mathrm{ml})$ of the column eluate were assayed for a total radiocarbon by LSC. Some effluents containing large amounts of radiocarbon were extracted with ethyl acetate (150 $\mathrm{ml} \times 3)$ at $\mathrm{pH} 1$. The ethyl acetate layer was combined, washed with sat. $\mathrm{NaCl}$ solution, dried over $\mathrm{Na}_{2} \mathrm{SO}_{4}$ and concentrated to dryness.

The air-dried soil samples were subjected to combustion analysis to examine the distribution of radiocarbon in the soil column. Some soil sections which contained large amounts of radioactivity were extracted twice with a mixture of $1 \mathrm{~N} \mathrm{HCl}(40 \mathrm{ml})$ and ethyl acetate $(60$ $\mathrm{ml}$ ) by blending for $10 \mathrm{~min}$. The ethyl acetate layers separated by centrifugation at $5000 \mathrm{rpm}$ for $10 \mathrm{~min}$ were combined, concentrated to dryness and analyzed by TLC.

\section{RESULTS}

\section{Degradation in Soils}

The degradation curves of cis- and trans-I in two soils are shown in Fig. 1. The initial halflife $\left(T_{1 / 2}\right)$ of disappearance was determined according to the following equations: $\ln Y=A-$ $B X, T_{1 / 2}=(\ln 2) / B$. The calculation was based on the residue data of 0-8 weeks for cis-I in Azuchi soil, of $0-4$ weeks for cis-I in Kuki soil and trans-I in Azuchi soil, and of 0-2 weeks for trans-I in Kuki soil. As a result, the half-lives were estimated to be 12.5 and 56.4 days for cis-I in Kuki and Azuchi soils, and 4.1 and 17.6 days for trans-I, respectively. The correlation coefficients $\left(r^{2}\right)$ were more than 0.96 in each case. After 168 days the concentrations of cisI decreased to $0.06 \mathrm{ppm}$ and $0.32 \mathrm{ppm}$, and those of trans-I to $0.03 \mathrm{ppm}$ and $0.09 \mathrm{ppm}$ in Kuki and Azuchi soils, respectively.

\section{Degradation Products in Soils}

The analysis by TLC showed that there were at least 9 degradation products in the extracts of the soils treated with either cyclopropyl- or phenyl $-{ }^{14} \mathrm{C} \mathbf{I}$ isomers. The products, separated by preparative TLC in solvent systems B, C, $\mathrm{D}$ and $\mathrm{E}$, were identified by one- or two-dimensional TLC cochromatography with synthesized compounds in the following solvent systems: cis- and trans-I (A); IV, V and VII $(\mathrm{B}, \mathrm{E})$; II and III $(\mathrm{B}, \mathrm{C})$; cis- and trans-VI (B, D). In addition, two minor products with the $R f$ values of 0.00 and $0.44-0.54$ (tailing) in solvent system $\mathrm{C}$ were detected. Although

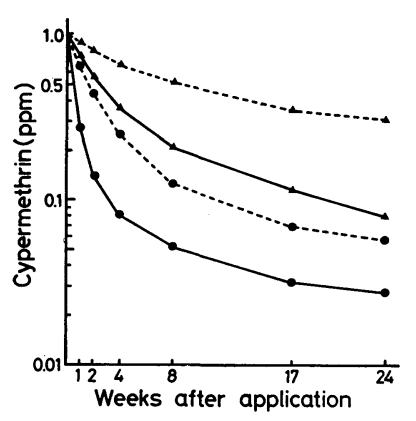

Fig. 1 The concentrations of cypermethrin in soils under aerobic upland conditions.

$\longrightarrow$, trans-isomers; ----, cis-isomers; ○, Kuki 
Table 3 The concentrations of cis- or trans-cypermethrin and its degradation products in Kuki soil stored for 14, 56, and 168 days under aerobic upland conditions.

\begin{tabular}{|c|c|c|c|c|c|c|c|c|c|c|c|c|}
\hline & \multicolumn{12}{|c|}{$\%$ of the applied ${ }^{14} \mathrm{C}$} \\
\hline & \multicolumn{6}{|c|}{ cis-Cypermethrin } & \multicolumn{6}{|c|}{ trans-Cypermethrin } \\
\hline & \multicolumn{3}{|c|}{ Cyclopropyl-14C } & \multicolumn{3}{|c|}{ Benzyl-14 C } & \multicolumn{3}{|c|}{ Cyclopropyl-14C } & \multicolumn{3}{|c|}{ Benzyl-14C } \\
\hline & 14 & 56 & 168 & 14 & 56 & 168 & 14 & 56 & 168 & 14 & 56 & 168 \\
\hline Volatile ${ }^{14} \mathrm{C}$ & 3.1 & 16.5 & 28.4 & 10.2 & 34.3 & 46.9 & 7.9 & 35.2 & 48.1 & 21.0 & 46.1 & 57.1 \\
\hline Polyurethane plug & $<0.1$ & $<0.1$ & $<0.1$ & $<0.1$ & $<0.1$ & $<0.1$ & $<0.1$ & $<0.1$ & $<0.1$ & $<0.1$ & $<0.1$ & $<0.1$ \\
\hline $\mathrm{NaOH}$ solution & 3.1 & 16.5 & 28.4 & 10.2 & 34.3 & 46.9 & 7.9 & 35.2 & 48.1 & 21.0 & 46.1 & 57.1 \\
\hline${ }^{14} \mathrm{CO}_{2}$ & 3.1 & 16.5 & 28.4 & 10.2 & 34.1 & 46.7 & 7.9 & 35.1 & 47.9 & 21.0 & 45.9 & 56.8 \\
\hline Others & $<0.1$ & $<0.1$ & $<0.1$ & $<0.1$ & 0.2 & 0.2 & $<0.1$ & 0.1 & 0.2 & $<0.1$ & 0.2 & 0.3 \\
\hline Extract ${ }^{14} \mathrm{C}$ & 58.0 & 21.5 & 9.0 & 47.9 & 18.1 & 7.3 & 19.9 & 6.9 & 3.3 & 15.6 & 6.0 & 3.1 \\
\hline$c i s-\mathbf{I}$ & 45.0 & 11.6 & 5.6 & 36.4 & 12.7 & 5.0 & - & - & - & - & - & - \\
\hline trans-I & - & - & - & - & - & - & 14.6 & 5.0 & 2.5 & 12.3 & 4.5 & 2.5 \\
\hline II & 1.5 & 0.9 & 0.3 & 1.7 & 0.9 & 0.4 & 0.3 & $<0.1$ & $<0.1$ & 0.3 & 0.1 & 0.2 \\
\hline III & 6.4 & 2.1 & 0.8 & 7.0 & 2.2 & 0.7 & 0.8 & 0.3 & 0.1 & 0.8 & 0.2 & 0.1 \\
\hline IV & 0.7 & 0.4 & 0.2 & 0.7 & 0.4 & 0.2 & 0.2 & 0.1 & $<0.1$ & 0.2 & 0.1 & 0.1 \\
\hline $\mathbf{V}$ & 0.2 & 0.5 & 0.2 & 0.3 & 0.5 & 0.2 & 0.1 & 0.1 & $<0.1$ & 0.2 & 0.1 & $<0.1$ \\
\hline$c i s-\mathbf{V I}$ & 1.0 & 1.5 & 0.2 & - & - & - & - & - & - & 一 & - & - \\
\hline trans-VI & - & - & - & - & - & - & 2.4 & 0.2 & 0.1 & - & - & - \\
\hline VII & - & - & - & 0.3 & 0.3 & 0.1 & - & - & - & 0.7 & 0.1 & $<0.1$ \\
\hline Others & 3.2 & 4.5 & 1.7 & 1.5 & 1.1 & 0.7 & 1.5 & 1.2 & 0.6 & 1.1 & 0.9 & 0.2 \\
\hline Bound ${ }^{14} \mathrm{C}$ & 33.8 & 57.6 & 57.1 & 31.2 & 41.0 & 40.3 & 62.7 & 49.8 & 45.1 & 55.2 & 41.3 & 37.7 \\
\hline Fulvic acid & 2.0 & 6.7 & 6.2 & 7.4 & 13.2 & 13.2 & 3.8 & 7.5 & 7.6 & 8.7 & 12.8 & 11.5 \\
\hline Humic acid & 6.1 & 5.0 & 6.6 & 13.1 & 14.2 & 14.6 & 10.9 & 9.9 & 9.7 & 25.5 & 13.1 & 13.5 \\
\hline Humin & 25.7 & 45.9 & 44.3 & 10.7 & 13.6 & 12.5 & 48.0 & 32.4 & 27.8 & 21.0 & 15.4 & 12.7 \\
\hline Total ${ }^{14} \mathrm{C}$ & 94.9 & 95.6 & 94.5 & 89.3 & 93.4 & 94.5 & 90.5 & 91.9 & 96.5 & 91.8 & 93.4 & 97.9 \\
\hline
\end{tabular}

they were not identified, they amounted in total to $0.2-5.3 \%$ of the applied ${ }^{14} \mathrm{C}$. It was found that they were neither of VIII, IX, 3phenoxybenzyl alcohol, 3-phenoxybenzaldehyde nor the hydroxy derivative oxydized at the 2-position of the phenoxy group of I. No cis/trans isomerization occurred in soils, which was evidenced the recovery of cis-VI and transVI from the soils treated with cis-I and trans-I, respectively.

The amount of degradation products in Kuki and Azuchi soils was listed in Tables 3 and 4. Although all of the identified products were common to both cis- and trans-I, there was a considerable variation in amount of degradation products between the two isomers. In soils treated with the trans-isomer, the ester cleavage products such as trans-VI and/or VII were of more importance than II and III. Trans-VI and VII amounted to $2.4-8.1 \%$ and
$0.7-2.9 \%$ of the applied ${ }^{14} \mathrm{C}$ after 14 days, but rapidly decreased thereafter. In contrast, the degradation products retaining the ester linkage like II and III were more predominantly formed in soils treated with cis-I. After 14-56 days II and III amounted to $7.4 \%$ and $7.0 \%$ of the applied ${ }^{14} \mathrm{C}$, respectively, and then both gradually decreased. Thus, these degradation products were not persistent in soils for a longer period of time. Meanwhile, IV and $\mathbf{V}$ amounted to less than $1 \%$ of the initial dose in all samples examined during the incubation period.

The extractable ${ }^{14} \mathrm{C}$ decreased steadily with a concomitant increase of the volatile and unextractable bound ${ }^{14} \mathrm{C}$. A large proportion of the volatile ${ }^{14} \mathrm{C}$ was trapped in the $\mathrm{NaOH}$ solution, with less than $0.1 \%$ of the applied ${ }^{14} \mathrm{C}$ in the polyurethane plug. The radiocarbon trapped in the alkaline solution was considered to be all ${ }^{14} \mathrm{CO}_{2}$, since 96.2 to $99.9 \%$ of the radio- 
Table 4 The concentrations of cis- or trans-cypermethrin and its degradation products in Azuchi soil stored for 14, 56, and 168 days under aerobic upland conditions.

\begin{tabular}{|c|c|c|c|c|c|c|c|c|c|c|c|c|}
\hline & \multicolumn{12}{|c|}{$\%$ of the applied ${ }^{14} \mathrm{C}$} \\
\hline & \multicolumn{6}{|c|}{ cis-Cypermethrin } & \multicolumn{6}{|c|}{ trans-Cypermethrin } \\
\hline & \multicolumn{3}{|c|}{ Cyclopropyl-14C } & \multicolumn{3}{|c|}{ Benzyl-14C } & \multicolumn{3}{|c|}{ Cyclopropyl-14C } & \multicolumn{3}{|c|}{ Benzyl- ${ }^{14} \mathrm{C}$} \\
\hline & 14 & 56 & 168 & 14 & 56 & 168 & 14 & 56 & 168 & 14 & 56 & 168 \\
\hline Volatile ${ }^{14} \mathrm{C}$ & 2.8 & 13.1 & 21.4 & 6.3 & 21.0 & 35.4 & 10.8 & 38.1 & 52.2 & 21.1 & 48.0 & 61.0 \\
\hline Polyurethane plug & 0.1 & 0.1 & 0.1 & $<0.1$ & $<0.1$ & $<0.1$ & $<0.1$ & $<0.1$ & $<0.1$ & $<0.1$ & $<0.1$ & $<0.1$ \\
\hline $\mathrm{NaOH}$ solution & 2.7 & 13.0 & 21.3 & 6.3 & 21.0 & 35.4 & 10.8 & 38.1 & 52.2 & 21.1 & 48.0 & 61.0 \\
\hline${ }^{14} \mathrm{CO}_{2}$ & 2.7 & 12.7 & 20.5 & 6.3 & 20.9 & 35.2 & 10.8 & 37.9 & 51.5 & 21.1 & 47.9 & 60.8 \\
\hline Others & $<0.1$ & 0.3 & 0.8 & $<0.1$ & 0.1 & 0.2 & $<0.1$ & 0.2 & 0.7 & $<0.1$ & 0.1 & 0.2 \\
\hline Extract ${ }^{14} \mathrm{C}$ & 89.5 & 68.2 & 51.4 & 84.9 & 65.1 & 39.2 & 64.3 & 25.2 & 12.9 & 57.8 & 23.0 & 9.1 \\
\hline$c i s-\mathbf{I}$ & 78.4 & 51.4 & 34.9 & 76.3 & 52.6 & 30.0 & - & - & - & - & - & - \\
\hline trans-I & - & - & 一 & - & - & - & 50.1 & 18.7 & 8.7 & 48.8 & 18.4 & 7.1 \\
\hline II & 4.3 & 7.4 & 6.1 & 4.5 & 7.0 & 5.5 & 2.1 & 1.3 & 0.6 & 2.3 & 1.4 & 0.7 \\
\hline III & 1.3 & 1.3 & 1.2 & 1.3 & 1.3 & 1.0 & 0.7 & 0.6 & 0.3 & 1.3 & 0.6 & 0.3 \\
\hline IV & 0.3 & 0.6 & 0.6 & 0.2 & 0.3 & 0.3 & 0.6 & 0.8 & 0.1 & 0.1 & 0.1 & 0.1 \\
\hline $\mathbf{V}$ & 0.1 & 0.3 & 0.3 & 0.2 & 0.2 & 0.3 & 0.1 & 0.2 & 0.1 & 0.3 & 0.2 & $<0.1$ \\
\hline$c i s-\mathbf{V I}$ & 2.1 & 1.9 & 3.2 & - & - & - & - & - & - & - & - & - \\
\hline trans-VI & - & - & - & - & - & - & 8.1 & 1.7 & 1.1 & - & - & - \\
\hline VII & - & 一 & - & 0.7 & 0.6 & 0.3 & - & - & - & 2.9 & 1.2 & 0.3 \\
\hline Others & 3.0 & 5.3 & 5.1 & 1.7 & 3.1 & 1.8 & 2.6 & 1.9 & 2.0 & 2.1 & 1.1 & 0.6 \\
\hline Bound ${ }^{14} \mathrm{C}$ & 7.9 & 18.0 & 24.3 & 7.7 & 14.2 & 21.2 & 22.4 & 31.5 & 28.9 & 19.0 & 23.5 & 26.5 \\
\hline Fulvic acid & 0.6 & 4.0 & 5.0 & 1.6 & 5.1 & 7.5 & 1.9 & 7.9 & 7.2 & 4.2 & 8.8 & 9.0 \\
\hline Humic acid & 2.3 & 2.9 & 3.6 & 3.2 & 4.8 & 6.6 & 5.6 & 6.1 & 6.1 & 7.8 & 7.2 & 9.2 \\
\hline Humin & 5.0 & 11.1 & 15.7 & 2.9 & 4.3 & 7.1 & 14.9 & 17.5 & 15.6 & 7.0 & 7.5 & 8.3 \\
\hline Total ${ }^{14} \mathrm{C}$ & 100.2 & 99.3 & 97.1 & 98.9 & 100.3 & 95.8 & 97.5 & 94.8 & 94.0 & 97.9 & 94.5 & 96.6 \\
\hline
\end{tabular}

carbon was precipitated as $\mathrm{Ba}^{14} \mathrm{CO}_{3}$. After 168 days ${ }^{14} \mathrm{CO}_{2}$ amounted to $28.4-56.8 \%$ and $20.5-60.8 \%$ of the applied ${ }^{14} \mathrm{C}$ in $\mathrm{Kuki}$ and Azuchi soils, respectively. A larger amount of ${ }^{14} \mathrm{CO}_{2}$ was evolved from the soils treated with trans-I and the benzyl- ${ }^{14} \mathrm{C}$ preparation (Fig. 2).

The bound ${ }^{14} \mathrm{C}$ in Kuki and Azuchi soils amounted to $37.7-62.7 \%$ and $19.0-31.5 \%$ of the applied ${ }^{14} \mathrm{C}$ for trans-I, and $31.2-57.6 \%$ and $7.7-24.3 \%$ for cis-I. It was formed in larger amounts when the soils were treated with the cyclopropyl- ${ }^{14} \mathrm{C}$ preparation than with the benzyl- ${ }^{14} \mathrm{C}$ preparation (Fig. 3). The bound ${ }^{14} \mathrm{C}$ originating from cis-I in both soils gradually increased with time, whereas the one from trans-I in Kuki soil reached the maximum amount 14 days after treatment, and then gradually decreased.

Fractionation of the unextracted soil residues showed that more of the unextracted radio- activity was associated with the humin fraction in case of the cyclopropyl- ${ }^{14} \mathrm{C}$ preparation. In contrast, the bound ${ }^{14} \mathrm{C}$ was distributed in three fractions of fulvic acid, humic acid and humin in case of the benzyl- ${ }^{14} \mathrm{C}$ preparation. Thus, there was some difference in the distribution profile of the bound radiocarbon between the cyclopropyl- and benzyl- ${ }^{14} \mathrm{C}$ preparations. These evidences suggest that the bound ${ }^{14} \mathrm{C}$ residues mainly originate from the hydrolysis products. Approximately $40-50 \%$ of the ${ }^{14} \mathrm{C}$ in the fulvic acid fraction were extracted with ethyl acetate. I, VII and VI were detected in the extracts only in small amounts.

\section{Leaching}

The distribution of radiocarbon in the soil column and the eluate is shown in Table 5 . The results are presented as percentages of the applied radiocarbon. When either the soil 

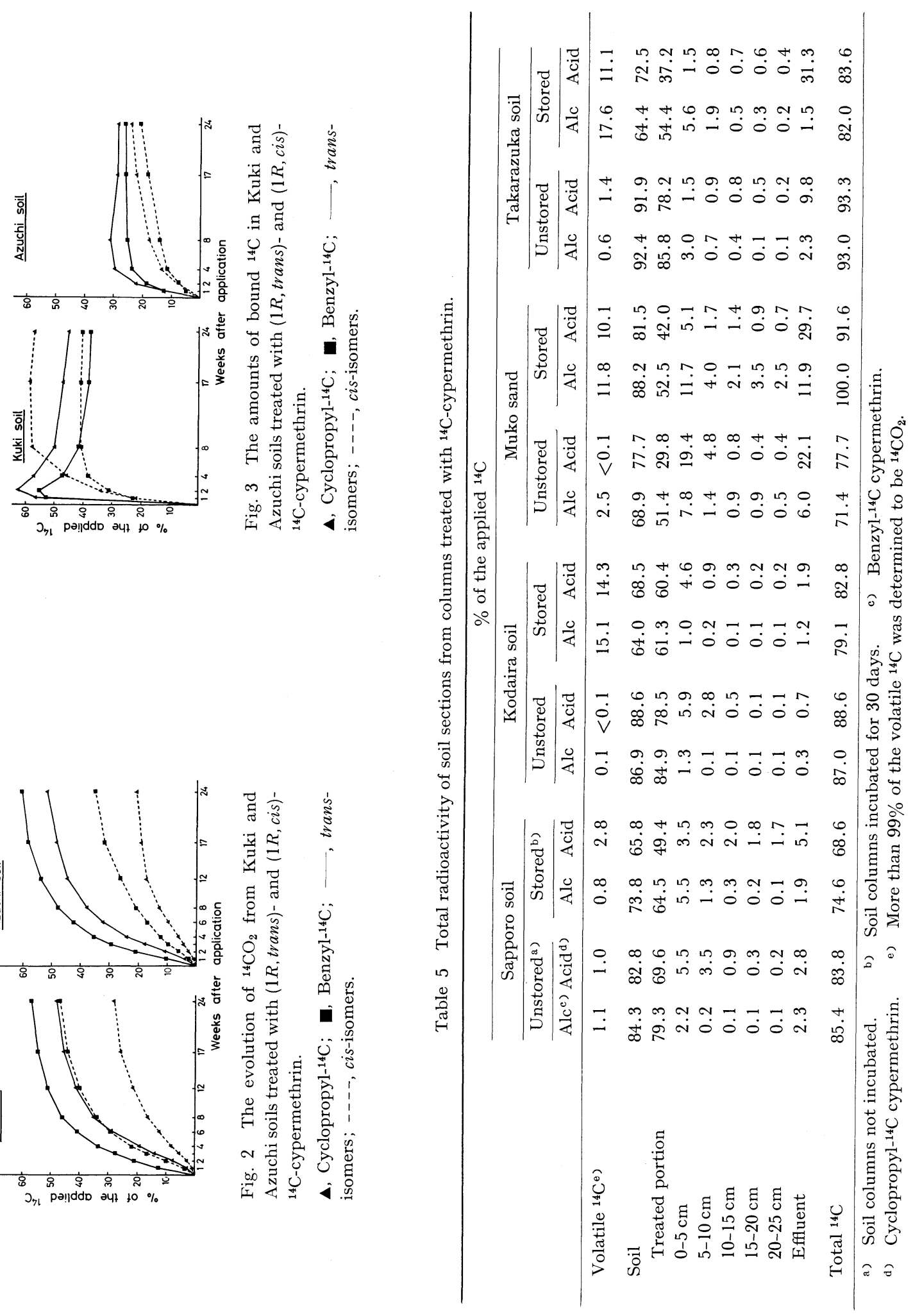
columns had been incubated (stored) or not incubated (unstored) before the leaching experiments, less than $5.1 \%$ of the applied ${ }^{14} \mathrm{C}$ appeared in the effluent from Kodaira and Sapporo soils containing relatively more organic matter, compared with 1.5 to $31.3 \%$ in the effluent from Takarazuka and Muko soils with less organic matter. ${ }^{14} \mathrm{C}$ was eluted in larger amounts from the soil columns treated with the cyclopropyl $-{ }^{14} \mathrm{C}$ preparations than from the ones treated with the benzyl- ${ }^{14} \mathrm{C}$ preparations. The major degradation products in the effluent were VI from the alcohol moiety and VII from the acid moiety, which amounted to $2.8-4.4 \%$ and $7.0-22.1 \%$ of the applied ${ }^{14} \mathrm{C}$, respectively. It appears that VI is more readily degraded further or bound to soils than VII during the leaching. In fact, bound ${ }^{14} \mathrm{C}$ amounted to 12.3 $30 \%$ of the applied ${ }^{14} \mathrm{C}$ in Takarazuka soil treated with the benzyl-label, compared with $5.1-18.1 \%$ in the one treated with the cyclopropyl-label. II, IV, VIII and IX were detected in the effluent only in small amounts. The unchanged I amounted to less than $0.3 \%$ of the applied radiocarbon.

The major part of the radiocarbon resided in the treated portion of each soil column. The exception was the Muko soil column, in which 5.1 to $19.4 \%$ of the applied ${ }^{14} \mathrm{C}$ appeared in the $0-5 \mathrm{~cm}$ fraction. The TLC analysis of each soil column showed the presence of a large amount of unchanged I together with a relatively small amount of II, IV, VI, VII and VIII.

During the percolation ${ }^{14} \mathrm{CO}_{2}$ was evolved from the soil columns, amounting to 0.1 to $2.5 \%$ under unstored conditions, and 0.8 to $17.6 \%$ under stored conditions (Table 5).

\section{DISCUSSION}

The half-life of disappearance in soils was 4.1 to 17.6 days for ( $1 R$, trans)-cypermethrin and 12.5 to 56.4 days for the $(1 R$, cis)-isomer under aerobic upland conditions. As estimated from the half-life values, the trans-isomer was degraded about 3 to 4 times more rapidly than the cis-isomer. The results were in accord with the previous observations, ${ }^{1,2)}$ in which $50 \%$ of the (1RS, trans)- and (1RS, cis)-isomers applied to soils were degraded in 2 weeks and 4 weeks, respectively.

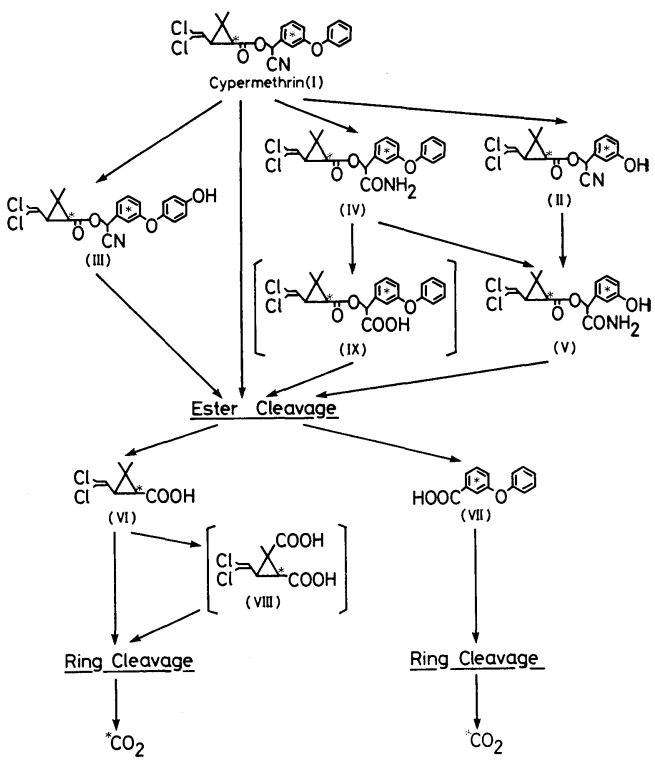

Fig. 4 Proposed degradation pathways for cypermethrin in soils.

[ ]; Degradation products of cypermethrin detected only in the leaching study.

Based upon the identified products, the proposed degradation pathways for $\mathbf{I}$ in soils are shown in Fig. 4. The insecticide underwent cleavage of the ester or diphenyl ether bond, hydroxylation at the 4-position of the phenoxy ring, and hydrolysis of the cyano group to the amide and carboxyl groups. The product unique to this experiment was II, which was considered to be formed at least in part via oxidation at the 2-position of the phenoxy ring followed by spontaneous cleavage of the diphenyl ether linkage. ${ }^{16,19)}$ In contrast, the dicarboxylic acid (VIII) oxidized at one of the gem-dimethyl groups of VI was not detected in the soil extracts. However, a trace amount of VIII appeared in the effluent from the soil columns. Their degradation profiles were very similar to those of other pyrethroids, namely permethrin, ${ }^{13,14)}$ fenpropathrin, ${ }^{15)}$ fenvalerate ${ }^{16)}$ and deltamethrin. ${ }^{17)}$ The main degradation route was hydrolysis of the ester linkage leading to the formation of VI and VII. The hydrolysis products were further degraded to ${ }^{14} \mathrm{CO}_{2}$ and/or bound to soils. Generally, ${ }^{14} \mathrm{CO}_{2}$ and bound ${ }^{14} \mathrm{C}$ residues were formed in large amounts in soils treated with the less persist- 
ent trans-isomer, whereas oxidation products retaining the ester linkage such as II and III were of more importance in soils treated with the cis-isomer. Although the previous study ${ }^{1)}$ showed that soils treated with cis-isomer of $\mathbf{I}$ contained both cis- and trans-isomers of VI, no cis/trans isomerization was observed in this experiment. It appears that VI is less susceptible to further degradation than VII, since the former was detected in soils of higher concentrations than the latter, and more rapid evolution of ${ }^{14} \mathrm{CO}_{2}$ occurred in soils treated with the benzyl- ${ }^{14} \mathrm{C}$ preparation. In contrast, somewhat a greater amount of bound ${ }^{14} \mathrm{C}$ was formed in soils treated with the cyclopropyl $-{ }^{14} \mathrm{C}$ preparation. There was a considerable variation in the distribution profiles of bound ${ }^{14} \mathrm{C}$ residues in the fulvic acid, humic acid and humin between the benzyl- and cyclopropyl- ${ }^{14} \mathrm{C}$ preparations. It appears that the bound ${ }^{14} \mathrm{C}$ stems mainly from the hydrolysis products. The bound ${ }^{14} \mathrm{C}$ residues arising from the trans-isomer of $\mathbf{I}$ in Kuki soils decreased with time, probably due to further degradation to carbon dioxide. Roberts and Standen ${ }^{2)}$ reported that the bound residues arising in soils from cis- and transisomers of $\mathbf{I}$ were further degraded to ${ }^{14} \mathrm{CO}_{2}$ when mixed with fresh untreated soils.

As with other pyrethroids, ${ }^{16,18)}$ leaching of cypermethrin in soils was limited, because of its quite low water solubility and rapid adsorption onto soil particles.

\section{REFERENCES}

1) T. R. Roberts \& M. E. Standen: Pestic. Sci. 8, 305 (1977)

2) T. R. Roberts \& M. E. Standen: Pestic. Sci. 12, 285 (1981)

3) A. N. Wright, T. R. Roberts, A. J. Dutton \& M. V. Doig: Pestic. Biochem. Physiol. 13, 71 (1980)

4) M. J. Crowford, A. Croucher \& D. H. Hutson: J. Agric. Food Chem. 29, 130 (1981)

5) M. J. Crowford, A. Croucher \& D. H. Hutson: Pestic. Sci. 12, 399 (1981)

6) L. O. Ruzo: J. Agric. Food Chem. 31, 1115 (1983)

7) N. Takahashi, N. Mikami, T. Matsuda \& J. Miyamoto: J. Pesticide Sci. 10, 629 (1985)

8) H. Kanamaru, M. Okuno, K. Kawahara, I. Nakatsuka \& A. Yoshitake: Abstr. Annu. Meet. Agric. Biol. Chem., Tokyo, p. 324, 1984

9) N. Mikami, N. Takahashi, K. Hayashi \& J.
Miyamoto: J. Pesticide Sci. 5, 225 (1980)

10) Anonymous: "Experiments in Agricultural Chemistry," ed. by Department of Agricultural Chemistry, Faculty of Agriculture, Kyoto University, Vol. I, Sangyo Tosho Publishing Co., Ltd., Kyoto, 1968 (in Japanese)

11) P. C. Kearney \& A. Konston: J. Agric. Food Chem. 24, 424 (1976)

12) Fed. Regist. 40, 26893 (1975)

13) H. Kaneko, H. Ohkawa \& J. Miyamoto: J. Pesticide Sci. 3, 43 (1978)

14) D. D. Kaufman, S. C. Hayes, E. G. Jordon \& A. J. Kayser: ACS Symp. Ser. 42, 147 (1977)

15) T. R. Roberts \& M. E. Standen: Pestic. Sci. 8, 600 (1977)

16) H. Ohkawa, K. Nambu, H. Inui \& J. Miyamoto: J. Pesticide Sci. 3, 129 (1978)

17) L.-Z. Zhang, S. U. Khan, M. H. Akhtar \& K. C. Ivarson: J. Agric. Food Chem. 32, 1207 (1984)

18) D. D. Kaufman, B. A. Russel, C. S. Helling \& A. J. Kayser: J. Agric. Food Chem. 29, 239 (1981)

19) L. C. Gaugham, T. Unai \& J. E. Casida: J. Agric. Food Chem. 25, 9 (1977)

要約

\section{ピレスロイド系殺虫剤サイパーメスリンの土壤 中での分解と溶脱}

坂田信以，三上信可，松田 正，宮本純之

ピレスロイド系殺虫刻サイパーメスリンのシス拈よび トランス異性体のシクロプロパン環もしくはベンジルフ ェニル環を ${ }^{14} \mathrm{C} て ゙$ 標識した化合物を用いて，土壤中での 分解と溶脱について検討した. トランス扣よびシス異性 体を 2 種類の土壌に $1 \mathrm{ppm}$ の割合で添加して好気的畑 地条件飞保つと, 消失半減期がそれぞれ 4.1 17.6日, 12.5 56.4日の速度で分解した. 主な分解経路はエステ ル結合の加水分解で, ほかにジフェニルェーテル結合の 開裂, フェニル環の水酸化, シアノ基の加水分解をうけ, 生成した分解物はさらに $\mathrm{CO}_{2}$ まで分解したり bound ${ }^{14} \mathrm{C}$ を形成した． ${ }^{14} \mathrm{CO}_{2}$ は，シス異性体より分解の速いトラ ンス異性体から，またシクロプロパン環 ${ }^{14} \mathrm{C}$ 標識体より フェニル環 ${ }^{14} \mathrm{C}$ 標識体からより多く生成した。一方, bound ${ }^{14} \mathrm{C}$ はシス異性体抢よびシクロプロパン環 ${ }^{14} \mathrm{C}$ 標 識体からより多く生成した. 有機物含量が $0.1 \%$ 以下で 粘土含量が $1 \%$ 以下の武庫砂の場合には, 処理直後に溶 脱を行ならと溶出液に微量のサイパーメスリンが検出さ れたが，他の土壤の場合には，処理直後および 30 日間 インキュベート後にかかわらず，溶出液中にはサイパー メスリンは検出されなかった. 